\title{
Occupational Health and Safety Risk Assessment on Informal Workers in Ogan Ilir, South Sumatra
}

\author{
Penilaian Risiko Keselamatan dan Kesehatan Kerja pada Pekerja Informal di \\ Ogan Ilir, Sumatera Selatan
}

\author{
Adisyah Fitrah Rahmadini, Desheila Andarini, Anita Camelia, Nurmalia Ermi, Novrikasari, Mona \\ Lestari \\ Public Health Science Study Program, Faculty of Public Health, Sriwijaya University \\ Indralaya, Ogan Ilir, South Sumatera, 30862 Indonesia
}

\begin{abstract}
Introduction: One of the blacksmith industry centers in South Sumatra is in Limbang Jaya I, Ogan Ilir. Informal businesses such as blacksmiths are businesses that do not have operational standards in their work processes. Various risks from the work process can, therefore, arise, from injury to hearing loss. Therefore, it is necessary to carry out risk analysis in the work of blacksmith sector using Preliminary Hazard Analysis. Methods: This study used a descriptive research method with a qualitative approach through in-depth interviews, hazard checklists, and PHA worksheets. There were 12 informants in this study consisting of 4 key informants and 8 blacksmith worker informants. Results: The results showed that the hazards identified based on the work process were physical hazards, chemical hazards, ergonomic hazards, and psychosocial hazards. The efforts could be made by performing audiometric checks on workers, working time arrangements, stretching before and after work, and the use of Personal Protective Equipment (PPE). Conclusion: Based on the results of risk ranking, it is known that out of 34 lists of hazards that existed in the blacksmith's work process in Limbang Jaya 1 Village, there were 8 types of hazards included in the high risk group, 12 hazards included in the serious risk group, 12 hazards included in the medium risk group, and 2 hazards included in the low risk group.
\end{abstract}

Keywords: blacksmith, preliminary hazard analysis, risk management

\section{ABSTRAK}

Pendahuluan: Sentra industri pandai besi di Sumatera Selatan salah satunya berada di desa Limbang Jaya I, Ogan Ilir. Usaha informal seperti pandai besi merupakan usaha yang tidak memiliki standar operasional dalam proses pekerjaannya. Berbagai risiko dari proses kerja dapat ditimbulkan seperti luka hingga kehilangan pendengaran, oleh karena itu perlu dilakukan analisis risiko pada pekerjaan sektor pandai besi menggunakan Preliminary Hazard Analysis. Metode: Penelitian ini menggunakan metode penelitian deskriptif dengan pendekatan kualitatif melalui metode wawancara mendalam, hazard checklist, dan PHA worksheet. Informan dalam penelitian ini berjumlah 12 orang yang terdiri dari 4 informan kunci dan 8 informan pekerja pandai besi. Hasil: Hasil penelitian menunjukkan bahaya yang teridentifikasi berdasarkan proses kerja adalah bahaya fisik, bahaya kimia, bahaya keselamatan, bahaya ergonomi, dan bahaya psikososial. Upaya yang dapat dilakukan adalah melakukan pemeriksaan audiometri pada pekerja, pengaturan waktu kerja, melakukan peregangan sebelum dan sesudah bekerja, serta menggunakan Alat Pelindung Diri (APD). Simpulan: Berdasarkan hasil perangkingan risiko diketahui bahwa dari 35 daftar bahaya yang ada pada proses kerja pandai besi di Desa Limbang Jaya 1, terdapat 9 jenis bahaya yang termasuk dalam kelompok high risk, 12 bahaya termasuk dalam kelompok serious risk, 12 bahaya termasuk dalam kelompok medium risk, dan 2 bahaya termasuk dalam kelompok low risk.

Kata kunci: manajemen risiko, pandai besi, preliminary hazard analysis

Corresponding Author:

Desheila Andarini

Email: desheila_andarini@fkm.unsri.ac.id

Telephone: +62 857-6922-2243

\section{INTRODUCTION}

Economic development in the industrialization sector, both in the formal and informal sectors, has increased every year. The development of industrial growth and development also encourages an increase in work equipment, chemicals, and the use 
of machines in the production process. This results in a higher risk of occupational accidents and an increase in the source of hazards in the workplace. Furthermore, work accidents can cause direct and indirect losses such as damage to work equipment and machines, environmental damage, and the cessation of the production process (Saputri, 2019). Every year 2 million people die, and accidents injure 270 million people at work worldwide. In developing countries, work accidents are severe because in developing countries, including Indonesia, a high number of labor-intensive industries means that more workers are exposed to potential hazards (Pratama, 2015). In Indonesia, the number of accidents at work based on BPJS Ketenagakerjaan (2019) recorded 77,295 work accidents.

One of the blacksmith industry centers in South Sumatra is in Limbang Jaya I, Ogan Ilir, with 70\% of the village community working as blacksmith workers. Initially, the blacksmith industry in Limbang Jaya I only made traditional weapons, but as the development and demand grow, the manufacture of modern tools also developed such as tarps, tapping knifes, blades, and others. Furthermore, informal businesses such as blacksmiths are businesses that do not have operational standards in their work processes. Based on the results of preliminary observations on blacksmith workers in Limbang Jaya I village, it was found that workers did not use personal protective equipment (PPE) such as protective goggles, earplugs, masks, and those who did decided to use PPE that were not suitable for their use such as wearing gloves on their feet. Some of the potential hazards that can occur to blacksmiths are noise, awkward positions, and hot work climate with the risk of occupational diseases such as noiseinduced hearing loss, carpal tunnel syndrome, musculoskeletal disorders, heat stress, dehydration, and others (Angganata, 2019). The purpose of this study is, therefore, to determine the potential hazards and risks in blacksmith workers in Limbang Jaya 1 village and identify control measures that can be done to minimize the risk of work accidents using the Preliminary Hazard Analysis (PHA) method.

\section{METHODS}

This research design used a descriptive research method with a qualitative approach. The research method was carried out through in-depth interviews, hazard observation checklists, and PHA worksheets to analyze occupational safety risks through the
Preliminary Hazard Analysis (PHA) method in the work processes of blacksmith sector workers. There were 12 informants in this study consisting of 4 key informants and 8 blacksmith worker informants. This research was conducted in February 2021.

This study obtained the sources of data from primary data and secondary data. Primary data were obtained directly by the researchers through observations, in-depth interviews, hazard checklist documents, and PHA worksheets. Instruments used in this study were the hazard checklist, PHA worksheets, interview guidelines, Sound Level Meter, UV Meter, Wet Bulb Globe Temperature, Quick Exposure Check (QEC) sheet, and The Workplace Stress Scale sheet for hazard observation. For the results of in-depth interviews to be adequately recorded, a recording device was needed to record the entire interview, a note pad was needed to record the interview results, and a camera was needed to take records of the interviews conducted between the researchers and the respondents.

Data analysis began by calculating the probability and severity value to obtain the risk value. The probability was measured according to the MIL-STD-882C standard consisting of frequent (A): may occur at any time, probable (B): may occur frequently, Occasional (C): may occur occasionally, remote (D): may occur infrequently but may still occur, and Improbable (E): is likely to occur infrequently. The Severity measure according to the MIL-STD-882C standard consisted of Catastrophic (I) which causes death to large losses, Critical (II) with the category of severe injury to major system damage, Marginal (III) with moderate injury to large financial losses and the need for medical treatment, and Negligible (IV) with moderate injury category. The ranking was carried out to determine the level of risk accepted by using a risk matrix based on the MIL-STD-882B standard. Hazards in the high risk category (1-5) are categorized as unacceptable hazards so that further control is needed to reduce risk. Hazards with serious/severe risk category (6-9) are categorized as unwanted hazards, so it is necessary to manage the activity process to determine hazard control. Hazards in the Medium Risk category (10-17) require regular monitoring in the implementation of activities. Meanwhile, hazards in a low risk category (18-20) are categorized as acceptable hazards.

The risk values were then sorted so that the risk rank could be seen from the lowest risk to the highest risk. Furthermore, the scores obtained were 
then compared with those in the the predetermined standard to see whether the risk was still acceptable or not; thus, it is necessary to control the risk by reducing it to a permissible limit. This research was conducted after obtaining approval from the ethics committee and research permission from the Faculty of Public Health, Sriwijaya University No. 029/ UN9.FKM/TU.KKE/2021.

\section{RESULTS}

Based on the results of hazard identification and risk assessment, there were 34 hazard lists that existed in the blacksmith's work process in Limbang Jaya 1 village. Eight types of hazards that were included in the high-risk group, 12 threats were

Table 1. Results of Hazard Identification and Risk Assessment in Blacksmith Workers

\begin{tabular}{|c|c|c|c|c|}
\hline Risk & Probability & Severity & $\begin{array}{c}\text { R i s k } \\
\text { Rank }\end{array}$ & Comment \\
\hline \multicolumn{5}{|c|}{ Iron Cutting Process } \\
\hline $\begin{array}{l}\text { Sharp } \\
\text { object }\end{array}$ & $\mathrm{C}$ & III & 11 & Medium \\
\hline $\begin{array}{l}\text { Hammer } \\
\text { hitting }\end{array}$ & $\mathrm{C}$ & III & 11 & Medium \\
\hline $\begin{array}{l}\text { Sharp } \\
\text { iron }\end{array}$ & $\mathrm{B}$ & III & 9 & Serious \\
\hline Noise & A & II & 3 & High \\
\hline $\begin{array}{l}\text { Join the } \\
\text { hot work }\end{array}$ & A & III & 7 & Serious \\
\hline Lighting & A & III & 11 & Medium \\
\hline $\begin{array}{l}\text { Awkward } \\
\text { posture }\end{array}$ & A & II & 3 & High \\
\hline \multicolumn{5}{|c|}{ Iron Forming Process } \\
\hline $\begin{array}{l}\text { Hammer } \\
\text { hitting }\end{array}$ & $\mathrm{C}$ & III & 11 & Medium \\
\hline Hot iron & $\mathrm{B}$ & III & 9 & Serious \\
\hline $\begin{array}{l}\text { Hot iron } \\
\text { splash }\end{array}$ & $\mathrm{B}$ & II & 5 & High \\
\hline $\begin{array}{l}\text { Iron } \\
\text { particle } \\
\text { dust }\end{array}$ & A & II & 3 & High \\
\hline Noise & A & II & 3 & High \\
\hline $\begin{array}{l}\text { Hot-work } \\
\text { climate }\end{array}$ & A & III & 7 & Serious \\
\hline Lighting & A & III & 11 & Medium \\
\hline $\begin{array}{l}\text { Electric } \\
\text { current }\end{array}$ & $\mathrm{D}$ & I & 8 & Serious \\
\hline $\begin{array}{l}\text { Charcoal } \\
\text { dust }\end{array}$ & $\mathrm{C}$ & IV & 18 & Low \\
\hline $\mathrm{CO}$ & $\mathrm{D}$ & I & 8 & Serious \\
\hline
\end{tabular}

\section{Continued Tabel 1}

\begin{tabular}{|c|c|c|c|c|}
\hline Risk & Probability & Severity & $\begin{array}{c}\text { R i s k } \\
\text { Rank }\end{array}$ & Comment \\
\hline Fire & $\mathrm{D}$ & I & 8 & Serious \\
\hline $\begin{array}{l}\text { Awkward } \\
\text { posture }\end{array}$ & A & II & 3 & High \\
\hline $\begin{array}{l}\text { Work } \\
\text { stress }\end{array}$ & $\mathrm{D}$ & III & 14 & Medium \\
\hline \multicolumn{5}{|c|}{ Grinding Process } \\
\hline $\begin{array}{l}\text { Electric } \\
\text { current }\end{array}$ & $\mathrm{D}$ & I & 8 & Serious \\
\hline $\begin{array}{l}\text { Grinding } \\
\text { stone }\end{array}$ & $\mathrm{C}$ & II & 6 & Serious \\
\hline Noise & A & II & 3 & High \\
\hline Sparks & B & III & 9 & Serious \\
\hline $\begin{array}{l}\text { Sharp } \\
\text { object }\end{array}$ & $\mathrm{C}$ & III & 11 & Medium \\
\hline Lighting & A & III & 11 & Medium \\
\hline $\begin{array}{l}\text { Hot-work } \\
\text { climate }\end{array}$ & A & III & 7 & Serious \\
\hline Iron dust & $\mathrm{C}$ & IV & 18 & Low \\
\hline Awkward & A & II & 3 & High \\
\hline \multicolumn{5}{|c|}{ Gilding Process } \\
\hline Hot iron & $\mathrm{C}$ & III & 11 & Medium \\
\hline $\begin{array}{l}\text { Sharp } \\
\text { iron }\end{array}$ & $\mathrm{C}$ & III & 11 & Medium \\
\hline $\begin{array}{l}\text { Plating } \\
\text { water }\end{array}$ & B & IV & 16 & Medium \\
\hline Lighting & A & III & 11 & Medium \\
\hline $\begin{array}{l}\text { Work } \\
\text { climate }\end{array}$ & A & III & 7 & Serious \\
\hline
\end{tabular}

included in the severe risk group, 12 threats were included in the medium-risk group, and 2 hazards were included in the low-risk group.

Follow-up efforts were made based on the level of risk that existed to minimize the risk of accidents. Hazards with a value of 1 to 5 were included in the unacceptable hazard group. Follow-up is needed to reduce the risk of work accidents by making alternative controls against existing hazards. Hazards with a value of 6 to 9 were included in the severe group as undesirable hazards, so that it is necessary to manage the work process to determine hazard control. Hazards that had a value of 10-17 were included in the medium group, which means that the hazards in this group are still acceptable but need regular monitoring in their implementation. Hazards with a value of 18 to 20 were included in the low group, so these hazards have a low risk and follow-up control is not needed. Furthermore, hazard control measures can be carried out using 
a hierarchy of management approach. Rules in the form of engineering control, administrative control, and the use of personal protective equipment (PPE) on blacksmith workers must, therefore, be carried out.

\section{DISCUSSION}

\section{Identification of Potential Hazards in Blacksmith Workers}

The sharp hammers used when splitting can injure workers' hands and fingers if workers are not careful while working. The blunt hammer can damage the workers' feet if they are placed carelessly and fall. Almost all blacksmith workers did not use gloves and shoes when working, and this caused workers to get injured due to the tools used while working. If workers do not use personal protective equipment (PPE) and are not careful when working, they can have accidents such as being punctured and scratched by sharp objects (Alma et al., 2019). This isin line with the statement by Rudyarti (2017), suggesting that there was a relationship between the attitude of using PPE with the incidence of work accidents in workers, which means that if the use of PPE is good, the incidence of work accidents will decrease. The hammer can injure the finger of the workers holding the chopping hammer if the workers are not careful. When the workers are cutting the iron, the hammer and splitting hammer can collide and hurt workers, especially resulting in head injuries. This is further supported by Tana's (2015) research, stating that the proportion of injuries to informal workers in Indonesia was higher than that of workers in business or construction.

Besides, the iron beating process can produce hot and sharp iron sparks and iron particle dust. From the results of interviews with eight blacksmith workers, the hot and robust iron sparks often caused wounds on the workers' skin, but the wounds tended to be ignored. Hot iron splashes can also cause eye injury to workers if workers do not wear protective glasses. The dust of iron particles in the form of $\mathrm{Fe}$ (iron dust) and $\mathrm{Si}$ (silica dust) can endanger workers' health if workers are exposed to specific concentrations continuously. Exposure to silica dust on blacksmith workers can threaten the health of workers' lungs with a long-term effect in the form of pneumoconiosis, which is a chronic effect of silica crystals (Regia and Oginawati, 2017).
The next hazard was generated from the combustion process, namely charcoal dust and $\mathrm{CO}$ gas. $\mathrm{CO}$ exposure affects $\mathrm{COHb}$ levels in the blood, so that an increase in $\mathrm{COHb}$ in the blood can cause the body's cells to lack oxygen due to the large amount of $\mathrm{CO}$ gas that binds to hemoglobin (Khairina, 2019). Fire hazards during the combustion process can cause fires at the worksite. The potential for a fire to occur is relatively small because the size of the fire is always controlled during the ironforming process. Still, if a fire occurs, the impact is significant enough to harm workers.

Grinding machines used to crush iron pose many hazards to workers. First, the electric current connected to the grinding machine is a highvoltage electric current that can cause workers to be electrocuted and cause serious injury to death. Based on Wati (2020), an electric shock can be felt if the current flowing in the body is more than $5 \mathrm{~mA}$, and at a large current the electric current can burn skin and flesh. When workers dig the iron, the sparks produced can cause limb injuries and eye injuries to blindness if the workers do not use safety goggles. The grinding process has dust of iron material which can irritate the eyes of workers. Workers who inhale inorganic dust can also suffer from pneumoconiosis, which can cause restrictive lung function disorders (Husaini et al., 2016). If the dust accumulates for a long time in the small airways, it will cause chronic inflammation so that obstructive pulmonary function disorders can occur (Harahap, 2016).

Furthermore, there was the danger of noise in the cutting process that came from the sound of hammering and colliding iron. Based on the results of measurements in the field, it was found that all respondents were exposed to noise in the $95 \mathrm{dBA}$ to $105 \mathrm{dBA}$ range, which means that the noise intensity received exceeded the Threshold Value (NAB) set by the Regulation of the Minister of Manpower of the Republic of Indonesia No.5 of 2018 concerning Occupational Safety and Health. In the Work Environment, the permissible noise level in the work shift is $85 \mathrm{dBA}$. At an intensity of $85 \mathrm{dBA}$ and above, there is a possibility that after five years of work there will be $1 \%$ of workers experiencing hearing loss, and after ten years of work, there will be $3 \%$ of workers experiencing hearing loss, and after 15 years of work, the rate will increase to $5 \%$ (Ubaidilah, 2015).

Based on field observations, the water used for the gilding process was black and dirty because it had been used many times. This could irritate the 
skin of the workers' hands because the water had been contaminated with iron. Also, workers' hygiene was poor because workers washed their hands using the water in the gilding tub. Bad hand-washing habits will aggravate the skin condition of the workers (Garmini, 2018). Another physical hazard was the hot work climate in the blacksmith's workplace, in which the workers experienced heat exceeding the threshold value. Superheated environment can interfere with the body's adjustment mechanisms to various serious conditions and potentially lead to fatal conditions (Anggraini, 2018). This result is in line with Sari (2017), showing that of 35 respondents who worked in hot climates with temperatures of $32.22^{\circ} \mathrm{C}$ and $31.96^{\circ} \mathrm{C}$, there were 4 workers who were optimally dehydrated, 18 workers who were moderately dehydrated, and 13 workers who were severely dehydrated. Another form of physical hazard was the hazard of lighting in the work location, which exceeded the threshold value. Excessive sun exposure can have detrimental effects on health, such as the burning of human skin cells, pigmentation, and premature aging. Moreover, sun exposure has a strong association with melasma (Marianingrum and Sudarsono, 2019).

Another danger found was work stress on workers due to job demands in which workers had to complete target orders every day and suffer from the noise at work locations. If the noise occurs repeatedly and continuously beyond the adaptation of each individual, it will result in stress (Amir et al., 2019). This result is in line with Ningsih and Fitri's (2017) research, stating that workers who were exposed to noise exceeding the threshold value, had 2 times higher risk of experiencing work stress than workers who worked with noise below NAV.

\section{Risk Analysis}

Risk analysis was carried out by considering the likelihood and magnitude of the consequences to determine the amount of risk (Angganata, 2019). The danger of sharp objects and hammer had a risk value of 11 , which was included in the medium category. The impacts of this danger were in the form of wounds and injuries to the body, especially on the head, when the worker was being hit by a hammer. Furthermore, the danger of sharp iron and hot iron had a risk value of 9 , which was included in the medium category with the impact of wounds on the body. The frequency of the occurrence of hazards was included in the probable category, which means that there was a frequent possibility of workers being exposed to risks during work.

Hot iron splash and iron particle dust were included in the high-risk category because the impact of these hazards were critical. Workers can experience injuries to body parts and injuries to eyes to blindness. Furthermore, the noise generated from the sound of hammers and metal colliding can cause the risk of Noise-Induced Hearing Loss (NIHL) to workers. The risk value for noise hazards in this study was 3, with the severity level included in the critical category and the frequency of occurrences in the frequent type. NIHL decreases the hearing threshold due to noise exposure; WHO says that about $16 \%$ of deafness in adults is caused by noise in the workplace (Amalia, Rosa and Rochmawati, 2015). Besides, the hot work climate hazard had a risk value of 7 with a severe category where the hazard frequency was included in the frequent type. This hazard often occurred because workers were exposed to the danger for eight hours of work. According to Sunaryo and Sahri (2019), if the workforce is exposed to continuous heat, it can cause heat rash, heat cramp, heat syncope, heat exhaustion, heatstroke, dehydration, to hyperthermia. In addition, lighting had a risk value of 11 , which was included in the medium category because its severity was in the marginal type, and the frequency of hazards was in the frequent category.

Also, the work position of workers who tend to bend is closely related to the risk of MSDs interference. Awkward postures with manual handling further increase the risk of developing MSDs in workers. Besides, the high-risk work postures are carried out for more than 10 seconds or leg postures are kept for more than 2 hours a day (Rahman, 2017). Moreover, the danger of electric current, $\mathrm{CO}$, and fire had a risk value of 8 , which was included in the severe category. The frequency of occurrence was included in the remote category, which means that the possibility of occurring was rare but possible. The resulting impact was included in the catastrophic category because the effects could cause death and a significant loss.

Work stress hazard had a risk value of 14. It was included in the medium-risk category because the value of the frequency of its occurrence was in the remote category where it was likely to occur rarely but might still occur to workers. Exposure to noise, temperature, and lighting in the work environment significantly affects the incidence of work stress (Ningsih and Fitri, 2017). 
The danger of grinding stones had a risk of 6 . It was included in the severe category, with the severity included in the critical category. Grinding stones can cause injuries to the workers' body parts and irritation to the workers' eyes. Meanwhile, the risk of sparks generated during grinding had a risk score of 9 and was in a severe category because the frequency of hazards was included in the probable category. On the other hand, the danger of charcoal dust and dust of iron material was in a low category, with the severity included in the negligible category because these hazards only caused temporary irritation to the eyes and skin of the workers, so that they were classified as minor injuries. Also, the danger of plating water had a risk level of 16 . It was included in the medium category with the frequency of exposure included in the probable category, which means exposure to the hazard was likely to occur because workers worked every day and used electroplate iron.

\section{Risk Ranking}

After conducting a risk analysis, all risks were grouped by types of risk and follow-up efforts. Risk ranking was carried out according to the MIL-STD228B standard. Based on the risk matrix, hazards considered high risk according to the MIL-STD882B standard are hazards with a value of 1 to 5 and are included in the unacceptable hazard category so that immediate hazard control follow-up is needed to minimize the risk (Angganata, 2019). The hazards that were included into the high-risk category in this study were noise during the cutting and grinding process, and awkward posture while cutting and grinding iron, as well as spattering hot iron.

Potential hazards included in the severe risk category based on the MIL-STD-882B risk matrix were possible hazards with a value of 6 to 9 , where hazards are included in hazards that require attention and control by managing work activities. The hazards that were included in the severe risk category in this study were sharp iron during the iron cutting process, hot working climate when cutting iron to plating iron, hot iron during the forming process, electric current used during the forming process of iron and grinding, $\mathrm{CO}$, fire, grinding stones, and sparks.

The hazards included in the risk medium according to the risk matrix are hazards with a value of 10 to 17 , which means that the danger is considered an acceptable hazard but requires regular monitoring in the implementation of activities (Fitriah, 2020). The hazards included in the medium-risk category in this study were sharp objects, hammers used to cut and shape iron, lighting during the cutting process to gilding, work stress, hot iron during gilding, and gilding water.

Potential hazards included in the low-risk category have a value of 18 to 20 , meaning that this hazard is acceptable. Hazards that were included in the low-risk category in this study were charcoal dust and dust from iron materials.

Based on the results of risk analysis, if the risk included in the unacceptable category, it is necessary to control the risk with alternative controls (Saputri, 2019). Follow-up efforts that can be carried out are based on the hierarchical control approach, namely engineering efforts, administrative efforts, and personal protective equipment.

Engineering efforts that can be done are making an acid chimney in a fireplace so that the workers do not directly inhale the $\mathrm{CO}$ gas that comes out during combustion. The fire used to burn iron carries a risk of fire. There should also be a barrier between the fireplace and workers to reduce the risk and impact of fire. Moreover, the electric current used in blowers and grinding machines can cause electric shocks to workers. The control that can be done is to carry out engineering to rearrange the work location and the electricity used so that the power cable is quite far from the workers but can still be reached (Angganata, 2019).

In addition, administrative efforts can be made in the form of periodic audiometric checks on workers. The examination on workers who experienced complaints should be carried out further

Table 2. Risk Matrix

\begin{tabular}{lcccc}
\hline \multirow{2}{*}{ Probability } & \multicolumn{4}{c}{ Severity } \\
\cline { 2 - 5 } & (I) Catastrophic & (II) Critical & (III) Marginal & (IV) Negligible \\
\hline Frequent (A) & 1 & 3 & 7 & 13 \\
Probable (B) & 2 & 5 & 9 & 16 \\
Occasional (C) & 4 & 6 & 11 & 18 \\
Remote (D) & 8 & 10 & 14 & 19 \\
\hline
\end{tabular}


using audiometric inquiries to determine the severity of the workers' suffering. For workers who do not give protest routinely, , this action must not be done too late (Minggarsari and Sahuri, 2019). Also, workers can rearrange the working time to reduce the exposure to hazards received by workers. To control the dangers of a hot work climate, workers can rest in places with cooler temperatures and increase their consumption of water (Anggraini, 2019). Workers can also stretch before and after work to reduce the risk of MSDs.

Control efforts done use personal protective equipment such as earplugs to reduce noise exposure, safety goggles, heat-resistant gloves, long-sleeved clothes that absorb sweat quickly, and masks. The use of ear protection equipment (APT) can reduce the noise level by some degree of dBA depending on the type of APT and the noise reduction of the APT. The use of APT can also serve to protect the ear canal from several types of hazardous work materials (Rahmawati, 2015).

Besides, the government needs to activate the Pos UKK (Pos Upaya Kesehatan Kerja) cadres who have been already serving in the Tanjung Batu health center to maintain the health of the blacksmith worker group in Limbang Jaya Village 1. The UKK post is a community-based health effort where all efforts are made, planned, organized from and for the active community. It is expected that through this program, the productivity of workers can increase (Denny et al., 2016). UKK post can provide training and increase workers' knowledge related to hazards in the workplace, such as the dangers of $\mathrm{CO}$ gas, fire, iron dust, and understanding of the importance of using personal protective equipment while working. The establishment and activation of the UKK post are highly expected so that workers can be empowered and can manage their health independently to improve the health status of workers.

\section{CONCLUSION}

Every blacksmith's work process, from cutting to gilding, has potential dangers. The potential hazards in the work process are noise, lighting at worksites, the hot working climate, dust from iron that hits during the cutting and shaping process, grinding material dust, dust from combustion, sharp pieces of iron due to the cutting and shaping process, hitting tools like hammers, grinding stones, the electric current used during the grinding process, working positions, repetitive movements, manual handling when cutting and shaping metal, work pressure to eventuate on workers. Based on the results of hazard identification and risk assessment, there were 34 hazard lists existing in the blacksmith's work process in Limbang Jaya 1 village; there were eight types of hazards that were included in the highrisk group, 12 threats included in the severe risk group, 12 threats included in the medium-risk group, and two hazards included in the low-risk group.

\section{ACKNOWLEDGEMENTS}

The author would like to express great gratitude to the Faculty of Public Health who have provided guidance and encouragement for the completion of this research.

\section{REFERENCES}

Alma, L. R. et al. (2019) 'Analisis Risiko Bahaya Pada Pekerja Di Tempat Penampungan Sampah Terpadu Reduce Reuse Recycle (Tpst 3r) Mulyoagung Bersatu Dau Kabupaten Malang', The Indonesian Journal of Public Health, 4(2), pp. 1-6.

Amalia, N., Rosa, I. and Rochmawati (2015) 'Hubungan Paparan Kebisingan Pada Pekerja Dengan Noise Induced Hearing Loss (Nihl) Di Ptpn Xiii Pms Gunung Meliau', Jurnal Mahasiswa dan Penelitian Kesehatan, 1(1), pp. 155-162.

Amir, J., Wahyuni, I. and Ekawati (2019) 'Hubungan Kebisingan, Kelelahan Kerja dan Beban Kerja Mental Terhadap Stres Kerja Pada Pekerja Bagian Body Rangka PT. X', Jurnal Kesehatan Masyarakat (e-Journal), 7(1), pp. 345-350.

Angganata, S. O. (2019) Preliminary Hazard Analysis Pada Pekerjaan Sektor Pandai Besi Di Desa Tanjung Laut Tahun 2019. Undergraduate Thesis. Indralaya: Faculty of Public Health, Universitas Sriwijaya.

Anggraini, I. (2019) Hubungan Iklim Kerja Panas Terhadap Kelelahan Kerja Sentra Industri Pandai Besi Desa Tanjung Laut Tahun 2019. Undergraduate Thesis. Indralaya: Faculty of Public Health, Universitas Sriwijaya.

Anggraini, P. (2018) Hubungan Iklim Kerja Panas dengan Kristalisasi Urin Pada Pekerja di Bagian Produksi PT Remco Palembang. Undergraduate Thesis. Indralaya: Faculty of Public Health, Universitas Sriwijaya.

BPJS Ketenagakerjaan (2019) Angka Kecelakaan Kerja. Jakarata: BPJS Ketenagakerjaan. 
Denny, H. M. et al. (2016) 'Pembentukan Pos Upaya Kesehatan Kerja pada Industri Kecil Pembuatan Alat Rumah Tangga Di Bugangan Kota Semarang', Jurnal Kesehatan Masyarakat, 10(1), pp. 45-48.

Fitriah, A. (2020) Penilaian Risiko Pada Pekerja Pandai Aluminium Di Kampung Sosial Kelurahan Majasari Prabumulih Selatan Tahun 2020. Undergraduate Thesis. Indralaya: Faculty of Public Health, Universitas Sriwijaya.

Garmini, R. (2018) 'Faktor Yang Mempengaruhi Kejadian Dermatitis Kontak Iritan pada Pekerja Pabrik Tahu', Jurnal Ilmiah Multi Science Kesehatan, 9(2), pp. 207-2017.

Harahap, L. (2016) Gambaran Kadar Debu dan Fungsi Paru pada Tenaga Kerja Bagian Gerinda di PT Perintis Sarana Pancing Indonesia. Undergraduate Thesis. Medan: Faculty of Public Health, Universitas Sumatera Utara.

Husaini et al. (2016) 'Studi Kasus; "Koreksi terhadap Pengukuran Polutan di Udara Unit Perajin Logam dan Dampaknya terhadap Kesehatan", Buletin Penelitian Kesehatan, 44(2), pp. 91-102.

Khairina, M. (2019) 'Gambaran Kadar CO Udara, $\mathrm{CoHb}$ dan Tekanan Darah Pekerja Basement Pusat Perbelanjaan X Kota Malang', Jurnal Kesehatan Lingkungan, 11(2), pp. 150-157.

Marianingrum, D. and Sudarsono (2019) 'Hubungan Lamanya Paparan Sinar Matahari Dengan Kejadian Melasma Pada Wanita Pemulung Di Tempat Pembuangan Akhir Telaga Punggur Kota Batam', Zona Kedokteran, 9(3), pp. 75-81.

Minggarsari, H. D. and Sahuri (2019) 'Hubungan Intensitas Kebisingan Dengan Keluhan Auditori Pada Pekerja Bagian Produksi Pabrik Fabrikasi Baja', Binawan Student Journal (BSJ), 1(3), pp. 137-141.

Ningsih, K. W. and Fitri, R. P. (2017) 'Pengaruh Lingkungan Fisik terhadap Terjadinya Stress Kerja pada Pekerja Industri Bengkel Las di Kota Pekanbaru', Jurnal Keperawatan Abdurrab, 1(1), pp. 27-32.

Pratama, A. K. (2015) 'Hubungan Karakteristik Pekerja Dengan Unsafe Action Pada Tenaga Kerja Bongkar Muat Di Pt. Terminal Petikemas Surabaya', The Indonesian Journal of Occupational Safety and Health, 4(1), pp. 64-73.

Rahman, A. (2017) Analisis Postur Kerja Dan Faktor Yang Berhubungan Dengan Keluhan Musculoskeletal Disorders (Msds) Pada Pekerja Beton Sektor Informal Di Kelurahan Samata Kecamatan Somba Opu Kabupaten Gowa Tahun
2017. Undergraduate Thesis. Makassar: Faculty of Medicine and Health Science, Universitas Islam Negeri Alauddin Makassar.

Rahmawati, D. (2015) Faktor-Faktor yang Berhubungan dengan Gangguan Pendengaran Pada Pekerja di Departemen Metal Forming dan Heat Treatment PT. Dirgantara Indonesia (Persero) Tahun 2015. Undergraduate Thesis. Jakarta: Faculty of Medicine and Health Science, Universitas Islam Negeri Syarif Hidayatullah.

Regia, R. A. and Oginawati, K. (2017) 'Potensi Bahaya Debu Silika Terhadap Kesehatan Pandai Besi Desa Mekarmaju Kabupaten Bandung', Jurnal Dampak, 14(2), p. 73.

Rudyarti, E. (2017) 'Hubungan Pengetahuan Keselamatan Dan Kesehatan Kerja Dan Sikap Penggunaan Alat Pelindung Diri Dengan Kejadian Kecelakaan Kerja Pada Pengrajin Pisau Batik Di PT. X', Prosiding Seminar Nasional Hasil-Hasil Penelitian Dan Pengabdian Bidang K3.

Saputri, T. D. (2019) Penilaian Risiko Keselamatan Kerja Pada Pengrajin Aluminium Di Desa Tanjung Atap Kecamatan Tanjung Batu Kabupaten Ogan Ilir Tahun 2019. Undergraduate Thesis. Indralaya: Faculty of Public Health, Universitas Sriwijaya.

Sari, M. P. (2017) 'Iklim Kerja Panas dan Konsumsi Air Minum Saat Kerja Terhadap Dehidrasi', HIGEIA (Journal of Public Health Research and Development), 1(2), pp. 108-118.

Sunaryo, M. and Sahri, M. (2019) 'Evaluasi Iklim Kerja di Bagian Produksi pada Industri Keramik di Wilayah Gresik', ARTERI : Jurnal Ilmu Kesehatan, 1(1), pp. 29-35.

Tana, L. (2015) 'Pada Kelompok Pekerja Usia Produktif Di Indonesia (The Contributing Factors to Injury 's Length of Stay in Hospital Among Productive Age Workers in Indonesia)', Buletin Penelitian Sistem Kesehatan, 19(29), pp. 75-82.

Ubaidilah, K. (2015) Hubungan Antara Umur Dan Lama Paparan Dengan Penurunan Daya Dengar Pada Pekerja Terpapar Kebisingan Impulsif Berulang Di Sentra Industri Pande Besi Desa Padas Karanganom Kabupaten Klaten. Undergraduate Thesis. Surakarta: Faculty of Health Science, Universitas Muhammadiyah Surakarta.

Wati, I. S. (2020) 'Potensi Bahaya pada Home Industry Konveksi', HIGEIA (Journal of Public Health Research and Development), 4(3), pp. 384-397. 